\title{
Author Recognition
}

AS IN THE CASE OF PREVIOUS WORK BY THE AUTHORS, THIS BOOK reflects the collaborative contribution of all members of the CAW (Canadian Auto Workers) Research Group on CAMI. From its inception in late 1989 , the Research Group was coordinated by David Robertson from the CAW national office. In addition to the authors of this book, members of the research group were Steve Benedict (CAW Local II2), Alan McGough (CAW Local 27), Herman Rosenfeld (CAW Local 303), and Jeff Wareham (CAW national office). The questionnaire items were formulated by the group, and all members conducted interviews at CAMI. We spent untold hours debating key research issues, and everyone contributed, either verbally or in writing, to virtually every chapter of this book. 
